American Journal of Economics and Business Administration 1 (2): 160-166, 2009

ISSN 1945-5488

(C) 2009 Science Publications

\title{
Distribution and Determining of Tourist Attractions and Modeling of Tourist Cities for the City of Isfahan-Iran
}

\author{
Seifolddini-Faranak, M. Shabani Fard and Hosseini Ali \\ Department of Geography and Urban Planning, University of Tehran, Iran
}

\begin{abstract}
Problem statement: Cities have different attractions and usually have tourists. But Management and development sustainable tourist activities needs planning. Approach: This research used survey method and taxonomy analysis to study the spatial pattern of tourist attractions in Isfahan city. Isfahan city is chosen because of numerous tourist attractions and its importance at national and regional level and also its multi role. The research was done from March to November 2008. Results: The result of statistical analysis shows that tourist attractions in Isfahan can be classified into four groups. Conclusion: On the basis of the result of study, the spatial pattern of tourist attractions is obtained that can be used for the management and planning based on the result a spatial model of tourism consumption in large cities was developed.
\end{abstract}

Key words: Tourist attractions, spatial tourist, spatial patterns, spatial distribution, Isfahan

\section{INTRODUCTION}

Cities have always been major destinations for tourists. The increase in the number of short trips to the cities shows that these destinations are one of the major tourist attractions ${ }^{[5-10]}$.

Cities in developing countries have multifunctions. Cities in developing countries are the gates for the entrance to the country, centers for staying and origins for the trips to rural areas and other tourist attractions. Cities have important role for tourist attractions ${ }^{[2-21]}$.

To understand tourism in cities, we need to consider cities as a product of tourism; a container that includes human activities and tourism activities [22-28] has classified tourist centers into following elements (Table 1).

Tourism has become an important economic source for planners and authorities in the field of city planning. It is one of the sources of competition in terms of investments, priority of goals, spatial organization of tourist spaces and establishing suitable commercial structure for tourist activities ${ }^{[6-18]}$. The important activity in planning and development of tourist activities is their classification and prioritization ${ }^{[8,9]}$.

In this research, classification of tourist attractions and their spatial pattern are determined on the basis of demand for tourists. There was a need to define the indicators of demand and supply for tourist activities. To apply evaluation methods and to use taxonomy.
Table 1: Primary elements

\begin{tabular}{ll}
\hline Activity place & Leisure setting \\
\hline Cultural facilities & Physical characteristics \\
Museums and art galleries & Historical street pattern \\
Theaters and cinemas & Interesting buildings \\
Concert halls & Ancients monuments and statues \\
Convention centers & Parks and green areas \\
Other visitor attractions & Waterfronts (harbor, canal, river) \\
Sport facilities & Socio-cultural features \\
Indoor and outdoor & Liveliness of the place \\
Amusement facilities & Language \\
Night clubs & Local customs and costumes \\
Casinos and bingo halls & Cultural heritage \\
Organized events & Friendliness \\
Festivals & Security \\
Secondary elements & Additional elements \\
Accommodation & Accessibility \\
Catering facilities & Transportation and parking \\
Shopping & Tourist information (maps, \\
Markets & sings, guides) \\
\hline
\end{tabular}

In this research, tourist attractions and their spatial distribution are analyzed on the basis of indicators that are associated directly with tourist activities. Taxonomy analysis is used to classify tourist attractions into homogenous clusters ${ }^{[27]}$.

The case study for this study is Isfahan city which is the center of Isfahan province. Isfahan is an important asset and unique in terms of existence of historical, cultural and religious buildings in Iran, middle East and Isfahan has an important industrial and cultural role at province and national level. Isfahan is well known as tourist pole and as a multi function city ${ }^{[15]}$.

Corresponding Author: Seifolddini- Faranak, Department of Geography and Urban Planning, University of Tehran, No. 309, Azin.Al, Ghods .St, Enghelab.Ave, Theran, Iran 
Literature review: The tourism literature has increased in the past few decades.

Studies have been done in the field of consumption and spatial distribution of tourists on the basis of variables and different methods.

Study by Raveh and Shoval ${ }^{[29]}$ studied Jerusalem and Tel Aviv. The percentage of visit, average length of stay, average number of visits was used to classify tourist attractions. On the basis of these variables, four classes of tourist attractions were obtained ${ }^{[13-29]}$.

Cooper ${ }^{[4]}$, who investigated the spatial behavior of tourists on the Channel Island of Jersey, identified differences in the spatial patterns of tourists according to two variables: stage in Life cycle and socioeconomic status. He found, that low-income tourists tended to visit only the major tourist attractions, whereas higher income tourists visited lower-order (less visited) attractions, as well. Chadefaud (1981) investigated the time-space patterns of pilgrims and tourists to Lourdes and presented detailed maps showing the activity spaces of organized groups and individual tourists; the former were more concentrated and the latter were more dispersed. Chadefaud offers two explanations for this finding: (1) tourists in organized groups tend to be older and, therefore, it is harder for them to explore the city by foot and (2) organized groups tend to consist ${ }^{[24]}$ More of pilgrims whereas a larger share of the individual visitors are tourists and not just pilgrims. Debbage ${ }^{[11]}$, who examined the spatial behavior of tourists in a resort in the Bahamas basing himself on Plog's ${ }^{[25]}$ tourist typology, found that differences in the spatial behavior of tourists resulted from differences in their personality structure $^{[25]}$ Prentice $^{[24]}$ found that the more affluent sectors of English society are more highly represented among visitors to heritage attractions and, in general, the visitors to these attractions tend to be older ${ }^{[25]}$. Light and Prentice (1994) reported similar findings regarding heritage attractions in Wales ${ }^{[26,7]}$.

Dietvorst $^{[3]}$, in his study of Enkhuizen, a small historic town in the Netherlands, identified several distinct tourist spaces based on differences in the main purpose of the visit to the town ${ }^{[3]}$. Montanari and Muscar"a $a^{[28]}$. outlined nine typical time-space profiles of tourists to Venice derived from a mix of the main purpose of their visit as well as other trip characteristics such as length of stay and previous visits to the city. Pearce $^{[7]}$ analyzed the characteristics, structure and functioning of three tourist districts in Paris. In his analysis he presented the differences of visitor patterns between international to French tourists. JansenVerbeke and Lievois ${ }^{[20]}$ highlighted both the theoretical and applied potential of the analysis of different time- space use patterns of urban tourists, using the historic city of Leuven in Belgium as a pilot study.

Yet another study focusing on the differential consumption of tourist sights is ${ }^{[3]}$ work on groups of Christian pilgrims of different denominations in Jerusalem. Bowman's work was followed up by Shachar and Shoval ${ }^{[29]}$ who identified segmented tourist spaces based on the different national and religious groups visiting the city. More recently, Shoval ${ }^{[32]}$ reexamined their findings using a statistical model consisting of 10 variables representing tourist and trip characteristics of visitors to Jerusalem. He concluded that religious difference was only one of the reasons explaining the differential consumption of tourists in Jerusalem and that the most influential variables explaining the spatial consumption of individual tourists are those related to the character of the trip, such as, length of stay in the city, main purpose of visit and number of visits to the city.

In summary, the literature are not abundant with researches on the subject of this study and the existing ones in most cases did not analyze the situations in large and multifunctional tourist cities.

\section{MATERIALS AND METHODS}

Survey method was used to collect data. The data for this study was collected from inbound individuals tourists who had visited the city of Isfahan in Iran, using questionnaires. The questionnaires were administered before they left of the hotels and tourist center's, information were used. The questionnaires were filled between March to September 2008. Five hundred tourists were the sample of study. Each questionnaire included a list of the tourist sights visited in city, along with a section covering their personal details and trip characteristics (Table 2). Also tourist attractions were defined; Taxonomy model is one of the ranking methods used in different fields. This method has been since 18 the century ${ }^{[19-30]}$ Recently, using this model has become common. According to a number of indicators, The Method classifies data into homogenous classes $^{[1-17]}$.

Taxononomy method is one of the methods of classification for planning and decision making. This method is able to classify data on the basis of indicators. Using these data, homogenous clusters can be defined and classified.

In this research, to classify tourists, tourists, (n) tourist attractions which have $(\mathrm{m})$ indicators were defined: 
Am. J. of Economics and Business Administration, 1 (2): 160-166, 2009

$$
\mathrm{x}=\left[\begin{array}{lllll}
\mathrm{x}_{11} & \mathrm{x}_{12} & \mathrm{x}_{13} & \ldots . . & \mathrm{x}_{1 \mathrm{~m}} \\
\mathrm{x}_{21} & \mathrm{x}_{22} & \mathrm{x}_{23} & \ldots . . & \mathrm{x}_{2 \mathrm{~m}} \\
\mathrm{x}_{31} & \mathrm{x}_{32} & \mathrm{x}_{33} & \ldots . . & \mathrm{x}_{3 \mathrm{~m}} \\
\vdots & & & & \\
\mathrm{x}_{\mathrm{n} 1} & \mathrm{x}_{\mathrm{n} 2} & \mathrm{x}_{\mathrm{n} 3} & \ldots . . & \mathrm{x}_{\mathrm{nm}}
\end{array}\right]
$$

In the above matrix, every column $\mathrm{n} \times \mathrm{m}$ is related to one observation and $\mathrm{m}$ indicators.

In the second stage table of standardized data are formed. Since different indicators are on the basis of different indicators, they are standardized. $\mathrm{Z}$ formula is used to standardize data and new matrix for standardized data is formed:

$$
\begin{aligned}
& \mathrm{Zij}=\frac{\mathrm{x}_{\mathrm{ij}}-\overline{\mathrm{x}}_{\mathrm{j}}}{\mathrm{sj}} \\
& \mathrm{X}=\left[\begin{array}{lllll}
\mathrm{z}_{11} & \mathrm{z}_{12} & \mathrm{z}_{13} & \ldots . . & \mathrm{z}_{1 \mathrm{~m}} \\
\mathrm{z}_{21} & \mathrm{z}_{22} & \mathrm{z}_{23} & \ldots . . & \mathrm{z}_{2 \mathrm{~m}} \\
\mathrm{z}_{31} & \mathrm{z}_{32} & \mathrm{z}_{33} & \ldots \ldots & \mathrm{z}_{3 \mathrm{~m}} \\
\vdots & & & & \\
\mathrm{z}_{\mathrm{n} 1} & \mathrm{z}_{\mathrm{n} 2} & \mathrm{z}_{\mathrm{n} 3} & \ldots \ldots & \mathrm{z}_{\mathrm{nm}}
\end{array}\right]
\end{aligned}
$$

Third step is to form the distance matrix. Considering matrix $\mathrm{z}$, we can define the distance of every observation for every indicator and then calculate the combined distance for observations:

$$
\mathrm{Dab}=\sqrt{\sum\left(\mathrm{z}_{\mathrm{aj}}-\mathrm{a}_{\mathrm{bj}}\right)^{2}}
$$

$a$ and $b$ are distances for two observations:

$$
\mathrm{Daa}=\circ \quad \mathrm{Dbb}=\circ \quad \mathrm{Dab}=\mathrm{Dba}
$$

Dij is the distance of is I from $\mathrm{j}$ in $(\mathrm{i}, \mathrm{j}, 1,2, \ldots . . \mathrm{n})$.

Matrix $D(n \times m)$, shows the combined distance of each observation from other observation. The matrix symmetrical:

$$
\mathrm{D}=\left[\begin{array}{lllll}
\circ & \mathrm{D}_{12} & \mathrm{D}_{13} & \cdots & \mathrm{D}_{1 \mathrm{~m}} \\
\mathrm{D}_{21} & \circ & \mathrm{D}_{23} & \cdots & \mathrm{D}_{2 \mathrm{~m}} \\
\mathrm{D} 31 & \mathrm{D} 32 & \circ & \cdots & \mathrm{D}_{3 \mathrm{~m}} \\
\vdots & \vdots & \vdots & & \vdots \\
\mathrm{D}_{\mathrm{n} 1} & \mathrm{D}_{\mathrm{n} 2} & \mathrm{D}_{\mathrm{n} 3} & \cdots & \mathrm{D}_{\mathrm{nm}}
\end{array}\right]
$$

Fourth stage is finding homogenous regions:

$$
\operatorname{Di}=\operatorname{Min} \operatorname{Dij} \mathrm{J}=1,2,3, \ldots \ldots . \mathrm{n} \mathrm{I} \neq \mathrm{J}
$$

Table 2: Characteristics of respondents

\begin{tabular}{llrl}
\hline Variable & Classifications & Numbers & Percentage \\
\hline Length of & 1-3 days & 102 & 25.50 \\
stay & 4-7 days & 175 & 43.75 \\
& More than 8 days & 123 & 30.75 \\
Purpose & Recreation visiting friends & 226 & 56.50 \\
of visit & and relatives & 80 & 20.00 \\
& Work-business & 76 & 19.00 \\
& Others & 19 & 4.50 \\
Sender & Male & 260 & 65.00 \\
& Female & 140 & 35.00 \\
Education & Elementary & 71 & 17.75 \\
& High school & 164 & 41.00 \\
& University & 165 & 41.25 \\
Number of & First & 118 & 29.50 \\
trips to & Second & 125 & 31.25 \\
Isfahan & Third on more & 157 & 39.25 \\
Location of & Hotel & 139 & 34.75 \\
stay & Hotel apartment & 64 & 16.00 \\
& Motel & 100 & 25.00 \\
& Bed and breakfast & 76 & 19.00 \\
& Friends and relatives & 21 & 5.52 \\
Source of & Brochure & 100 & 25.00 \\
information & Guide book & 92 & 23.00 \\
about the & Internet & 82 & 20.50 \\
trip & Mass media & 48 & 11.50 \\
& Friends & 80 & 20.00 \\
\hline
\end{tabular}

$$
\mathrm{di}=\left[\begin{array}{l}
\mathrm{d}_{1} \\
\mathrm{~d}_{2} \\
\vdots \\
\mathrm{d}_{\mathrm{n}}
\end{array}\right]
$$

To determine, homogenous observation, first we calculate mean and standard deviation of Di and its upper and lower level $\left(\mathrm{L}_{2}, \mathrm{~L}_{1}\right)$. This shows the distance of homogeneity. Observations out of this range are considered non-homogenious:

$$
\begin{gathered}
\mathrm{d}-\frac{\sum_{\mathrm{i}}^{\mathrm{n}}=1 \mathrm{di}}{\mathrm{n}} \\
\mathrm{sd}=\mathrm{v} \frac{\sum_{\mathrm{i}=1}^{\mathrm{n}}(\mathrm{di}-\overline{\mathrm{d}}-)^{2}}{\mathrm{n}} \\
\mathrm{L}_{1}=\overline{\mathrm{d}}+2 \mathrm{sd} \\
\mathrm{L}_{2}=\overline{\mathrm{d}}+2 \mathrm{sd} \\
\mathrm{L}_{1}<\mathrm{d}<\mathrm{L}_{2}
\end{gathered}
$$

Fifth stage is classification of homogenous observations, again The standardized matrix is formed for each one of homogenous groups and the largest number in relation to each indicator is found. This 
amount is an ideal amount. The distance of each observation from ideal observation is calculated and show it as Cio:

$$
\text { Cio }=\sqrt{\sum(\mathrm{zij}-\mathrm{zoj})^{2}}
$$

Zoj $=$ The maximum amount for indicator $\mathrm{j}$

$\mathrm{Zoj}=$ Max zij

The smaller Cio shows the smaller distance of observation i from ideal observation. On this basis, the observation can be classified.

\section{3:RESULTS}

The result of analysis shows that tourist attractions can be classified into four clusters (regions) according to the number of visits and type of visitors (Fig. 1).

Region 1: The central historical region and the area called Seeosepol (the name of a famous bridge (Fig. 1). The majority of tourist visit this Region 1 . The study of visitors that groups from different educational level (elementary, high school and university) visit the tourist attractions in this region. Tourists who stay at Isfahan city for at most seven day, visit this region. No major difference was observed between the number of female and male:

- Naghsheh Gahan square

- Shaigh Lotofolah Masque

- Imam Masque
- Ali Ghapoo palace

- Seeosepol bridge

- Ghaisarieh bazaar

- Ghaisarieh bazaar entrance

- Chehel setoon building

- Chahar Bagh complex

- Jameh Mosque

- Hasht Behesht Building

- Charhar Bagh school

- Recreation center

- Ashraf saloon

Region 2: Length of stay of visitors shows that these who have stayed between 4-7 days in Isfahan, visited these centers in Region 2. Visitors with high school and university degrees consisted the majority. Looking at variable Gender shows that female consist higher number than male. Visitors of Region 2 have also visited Region 1. Tourists attractions in Region 2 are on follows:

- Khajoo bridge

- Flower Gorden

- Birds Garden

- Water Fulls Park

- Bozorg bazaar

- Zargarha bazaar

- Honar bazaar

- Honar Museum

- Rangrazha bazaar

- Ferdosi Bridge

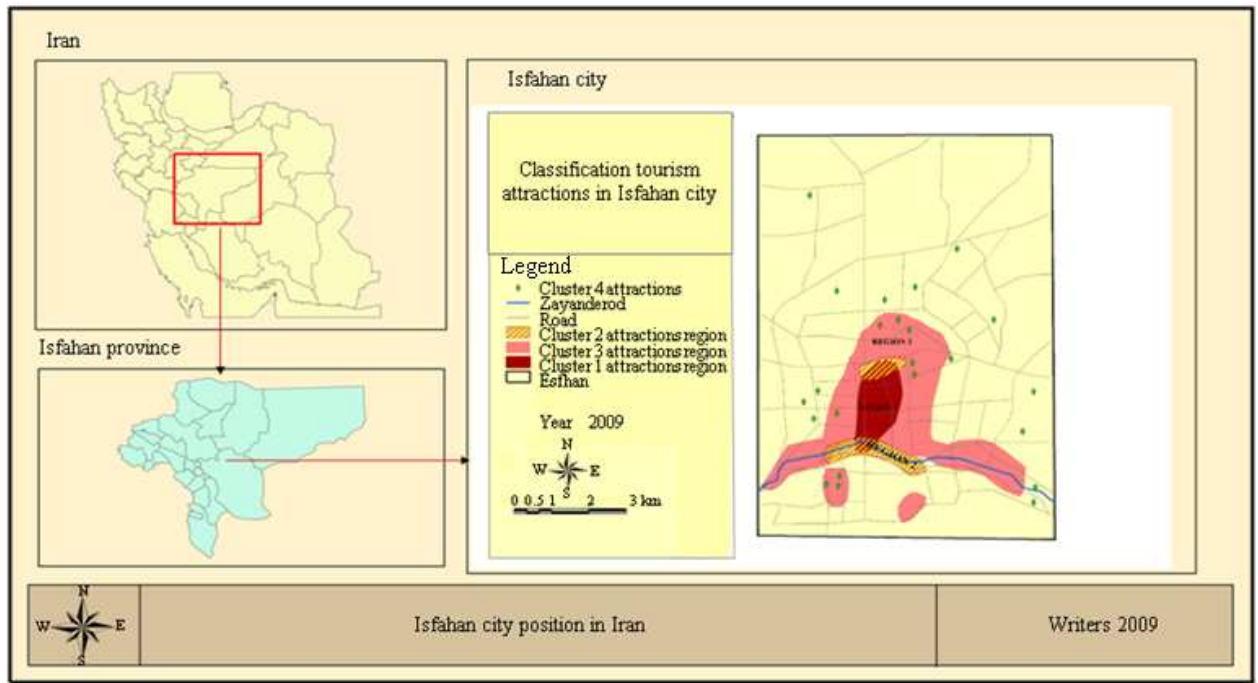

Fig. 1:Tourist attractions in Isfahan to taxonomy model 
Am. J. of Economics and Business Administration, 1 (2): 160-166, 2009

- Darol shafa bazaar

- Shishehgarha bazaar

- Mokhels saray

- Golshan saray

- Haj Karim saray

- Kodak Boston

- Tofang and shamshir bazaar

Region 3: Tourists who have stayed longer than 7 days and it is not their first time to stay in Isfahan (second on third time) have visited tourist attractions in Region 3. The majority of visitors of Region 3 have stayed at their relative's homes. Majority of visitors of this region have university degree. Looking at variable gender shows that majority of visitors of this region are male and female are less, unless they are married and with family. Tourist attractions in this region are:

- Najvan park

- Shahrestan Bridge

- Safeh park

- Folad Takht

- Leleh park

- Baba Roknoldin cemetery

- Shahsheham Boghah

- Ghasr Darb

- Baghoshkaneh park

- Isargarn park

- Zalyandeh rood Bostan

- Melat Bostan

- Aeneh Khaneh Bostan

- Abozar bridge

- Sadi Booston

- Osan commercial complex

- Carpet shopping center

- Vanak church

- Maryam church

- Chehel Dokhtaran Monareh

- Dardasht Monareh

- Sareban Monareh

- Shaigh Bahaee public bath

- Ghazvineha house

- Baitollham church

- Darolziafeh Monareh

- Petros house

- Darid house

- Jewish church

- Mesri Mosque

- Koshk Darb

- Malek Gorestan

- Ghazviniha Museum
- Lebnon Mosque

- Khat Museum

- Shohada Museum

- Halal Ahmar Museum

- Shaikholeslam house

- Safa Mosque

- Ali Agha public bath

- Jolfa chuch

- Bazi shahr

- Atashgah

- Monar Jonban

- Ghadir cultural complex

Region 4: Visitiors of this region have the highest level of education. These tourist attractions have longer distance from the city's downtown and have attracted less tourists. Most of the visitors are male. Female interested in this tourist attractions have high level of education and came to these tourist centers with special purpose. Tourist attractions in this region are:

- Japense garden

- Daeme exhibition

- Ibrahim Emam zadeh

- Khan Mosque

- Ghodsi house

- Laleh park

- Haghighi house

- Baba Ghasam cemetery

- Massod Boghaeh

- Haronieh Imam Zadeh

- Ismeel Imam zadeh

- Ahmad Imam Zadeh

- Ali Mosque

- Malek shahr complex

- Hassan Abad bazaar

- Yakob church

- Marta house

- Narsis church

- Bidabad bazaar

- Soltani complex

- Shahzadeghan Bogheh

- Mirza Kochek khan park

- Ghadir recreational cultural complex

\section{DISCUSSION}

Isfahan is unique city. It is an important historical center for main different group of tourists in the domestic and international in the world. The complexity of tourism Isfahan makes this city an excellent 
destination for urban tourism research .in this paper, the consumption of tourist attractions by tourists was analyzed toward to begin of 2000 period of prosperity in tourism in this city in middle east region. the data were analyzed using a statistical which enabled us to differentiate between tourist attraction based on the characteristic of tourist who visit it. however in our view, the approach presented in this paper is relevant to the analysis of tourism in other large cities and improve the planning and management in decision making for large tourism cities.

\section{CONCLUSION}

Isfahan is the heart of tourist centers in Iran at national level. Isfahan is a multi purpose city and every year, thousands people visit this city. Isfahan is a suitable city for tourist studies. To Since different variable play a role in hierarchical system of tourist attractions, there was a need the study these variables and spatial pattern of these visits.

This study was an attempt to use taxonomy model to find the cluster of tourist regions. Also, it was on attempt to determine the impact of variables (1) length of stay (2) education and (3) gender on the spatial pattern of visits. Study showed that tourist centers that are located in downtown and central part of city and are located in higher density Part of the city, receive more tourists. There is an association between length of stay, education, distance and visiting tourist Centers in the regions. Tourists who stay longer and have higher level of education visit more peripheral attractions Region 3 and 4 which are not located in central part of the city (Region).

The result of study showed that Region 1 with highest density of tourist centers has highest and more diverse number of tourists and there is not difference between the number of male and female visitors. These are special Christian and Jewish churches in region 3 and 4 that have Christian and Jewish tourists.

Using taxonomy model, four regions were determined that can be used for planning and management of tourist centers.

\section{REFERENCES}

1. Azar, A. and H. Faragi, 2001. Fazzi Management Science. Ejtemah, Tehran, ISBN: 964-93791-2-6, pp: 134-141.

2. Dinari, A., 2005. Urban Tourism in Iran and the World. Khord Vagegan Publication, Mashhad, ISBN: 964-8931-26-7, pp: 56-63.

3. Dietvorst, A.G.J., 1994. Cultural Tourism and Time-Space Behavior. Routledge, New York.
4. Cooper, A.P., 1991. Spatial and temporal patterns of tourist behavior. Region. Stud., 15: 359-371. DOI: $10.1080 / 09595238100185351$

5. Cazee and Potieh, 2003. Urban Tourism. Translation by Mohalati, Salahdin Shahid Beshti. University Publications, ISBN: 964-7689-34-2, pp: 127-134.

6. Ghee, C.H.Y., 1998. Qualitative Research Methods in Social Science, Translated by Dr. Ahmad Poor Ahmad and Dr. Shojaee, Ali. Yazd University Publications, Yazd, ISBN: 964-5808-42-1, pp: 345-353.

7. Pearce, D.G., 1986. Tourism Today: A Geographical Analysis. Longman, Burnt Mill, ISBN: 0-582-30145-9, pp:78-89.

8. Judd, D.R. and S.S. Fainstein, 1999. In The Tourist City. Yale University Press, New Haven, London, ISBN: 9780300078466, pp: 104-115.

9. Inskeep, E., 1991. Tourism Planning: An Integrated and Sustainable Development Approach. John Wiley and Sons, New York, ISBN: 0-47129392-X, pp: 451-462.

10. Chulk, G., 2003. Tourism in a Comprehensive View, Translated by Parsian and Arabi, Cultural Research Institute, ISBN: 964-6269-09-5, pp: 344-356.

11. Debbage, G., 1991. Spatial behavior in a Bahamian resort. Ann. Tourism Res., 18: 251-268. DOI: 10.1016/0160-7383(91)90008-Y

12. Ashworth, G.J., 1989. Accommodation and the historic city. Built Environ., 15: 92-100.

13. Lipshits, G. and A. Raveh, 1998. Socio-economic differences among localities: A New method of multivariate analysis. Region. Stud., 32: 747-757. DOI: 10.1080/00343409850119436

14. Asayesh, H., 2004. Regional Planning. Payam Noor Publications, Tehran, ISBN: 964-455-215-6, pp: 96-105.

15. Zendeh Del, H., 1999. Comprehensive Guide of Iran. Iran Gardan Publication, Isfahan Province, Tehran, ISBN: 964-6635-00-8, pp: 225-230.

16. Bennet, J.A. and J.W. Strydom, 2001. Introduction to Travel and Tourism Marketing, Juta, Johannesburg, ISBN: 0-7021-5636-1, pp: 94-109.

17. Ziari, K., 2009. Principle and Methods of Regional Planning. Yazd University Publication, Yazd, ISBN: 978-964-03-5905-2, pp: 104-115.

18. Lomsden, L., 2001. Marketing Tourism. Translated by Institate Ghoharian, Tehran. Cultural Research Institute, Iran, ISBN: 964-5799-20-1, pp: 145.

19. Bid Abad, M., 1998. Taxonomy Method and Classification of Development in Iran. 
20. Jansen-Verbeke, M. and E. Lievois, 1999. Analyzing Heritage Resources for Urban Tourism in European Cities. In: Contemporary Issues in Tourism Development, Pearce, D.G. and R.W. Butler, (Eds.). Routledge, London, New York, ISBN: 0415-20691-X, pp: 145-156.

21. Rahnemaee, M.T. and P. Shah Hosseyni, 2005. Process of Urban Planning in Iran. Tehran University, Iran, ISBN: 307-12160955, pp: 127-135.

22. Papoli Yazdi, M.H. and M. Saghaee, 2006. Tourism :Nature and Concepts. Samt, ISBN: 964530-086-X, pp: 233-235.

23. Hall, M. and S.J. Page, 2002. The Geography of Tourism and Recreation: Environment, Place and Space. 2nd Edn., Routledge, London, New York, ISBN: 0-415-33561-2, pp: 229-240.

24. Prentice, R., 1993. Tourism and Heritage Attractions. Routledge, London, New York, ISBN: 041508525X, pp: 67-74.

25. Plog, S.C., 1987. Understanding Psychographics in Tourism Research. In: Travel, Tourism and Hospitality Research: A Handbook for Managers and Researchers, Brent-Ritchie, J.R. and C.R. Goeldner (Eds.). Wiley, New York, ISBN: 9780471842255, pp: 93-112.

26. Page, S.J., 1995. Urban Tourism. Rouledege, London, New York, ISBN: 0415112184, pp: 142-152.
27. Mohalati, S., 2004. Sustainable Urban Tourism. Municipalities Monthly Magazine, Municipalities Publication, No. 46.

28.S.J.Page and M. C Hall, Managing urban tourism, Harlow: Prentice-Hall, ISBN: 0130272868, 9780130272867, 2003, pp.202-216.

29. Noam, S. and A. Raveh, 2004. Categorization of tourist attractions and modeling of tourist, cities based on the co-plot of multivatiate analysis. Tourism Manage., 25: 741-750. DOI: 10.1016/J.TOURMAN.2003.09.005

30. Bowman, W.M., 1993. AHP: Multiple Criteria Evolution. In: Spread Sheet Models for Urban and Regional Analysis/Boor and Disk, Brail, R.K., E.G. Bossard and R.E. Klosterman (Eds.). Center for Urban Policy Research, New Brunswick, ISBN: 10: 088285142X, pp: 467. 